\title{
Penerapan Metode Pembelajaran Menggunakan Ekstraksi Fitur dan Algoritma Klasifikasi untuk Identifikasi Pengenalan Iris
}

\author{
Rahmat Hidayat $^{1}$, Sarifah Agustiani ${ }^{2}$, Siti Khotimatul Wildah ${ }^{3}$, Ali Mustopa ${ }^{4}$, Rizky Ade Safitri $^{5}$ \\ ${ }^{1,2,3,4}$ Universitas Bina Sarana Informatika \\ 1e-mail: rahmat.rhh@bsi.ac.id \\ 2e-mail: sarifah.sgu@bsi.ac.id \\ 3e-mail: siti.ska@bsi.ac.id \\ ${ }^{4}$ e-mail: alimustopa.aop@bsi.ac.id
}

${ }^{5}$ STMIK Nusa Mandiri

${ }^{5}$ e-mail: rizky.rzs@nusamandiri.ac.id

\begin{tabular}{ccc}
\hline Diterima & Direvisi & Disetujui \\
$05-05-2021$ & $16-06-2021$ & $28-06-2021$ \\
\hline
\end{tabular}

\begin{abstract}
Abstrak - Iris mata terletak di antara kornea mata dan lensa mata, yang berfungsi untuk mengontrol intensitas atau jumlah cahaya yang masuk dengan cara melebarkan dan mengecilkan pupil. Setiap orang memiliki iris yang berbeda dan memiliki stabilitas sepanjang hidup, kecuali terjadi kerusakan yang tidak disengaja pada iris seperti terjadi kecelakaan. Tujuan dari penelitian ini adalah untuk melakukan pengklasifikasian dan identifikasi pengenalan citra iris dengan menggunakan metode pembelajaran atau machine learning. Metode yang diusulkan dalam penelitian ini adalah penerapan ekstraksi fitur seperti HOG, Hu-Moments, dan Haralick dengan algoritma klasifikasi yang terdiri dari LR, LDA, KNN, RF, CART, NB, dan SVM. Berdasarkan hasil pengujian yang telah dilakukan dalam mengklasifikasikan iris dapat disimpulkan bahwa penggunaan ekstraksi fitur sangat berpengaruh pada nilai akurasi yang dihasilkan. Dalam hal ini nilai akurasi terbaik diperoleh dari penggabungan ekstraksi fitur HOG dan haralick pada algoritma Random Forest dengan nilai akurasi sebesar 81.38\%.
\end{abstract}

Kata Kunci: Iris; Ekstraksi Fitur; Algoritma Klasifikasi

\begin{abstract}
The iris is located between the cornea of the eye and the lens of the eye, which serves to control the intensity or amount of light entering by dilating and shrinking the pupil. Everyone has a different iris and has stability throughout life, unless there is accidental damage to the iris as an accident occurs. The purpose of this study is to classify and identify iris image recognition using learning methods or machine learning. The method proposed in this study is the application of extraction features such as $\mathrm{HOG}, \mathrm{Hu}-\mathrm{Moments,}$ and Haralick with classification algorithms consisting of $L R, L D A, K N N, R F, C A R T, N B$, and SVM. Based on the results of tests that have been conducted in classifying irises it can be concluded that the use of feature extraction greatly affects the accuracy value produced. In this case the best accuracy value is obtained from combining hog and haralick feature extraction in Random Forest algorithm with an accuracy value of $81.38 \%$.
\end{abstract}

Keywords: Iris; Feature Extraction; Classification Algorithm.

\section{PENDAHULUAN}

Banyak penelitian telah dilakukan untuk pengenalan atau identifikasi manusia sejak lama, sebelumnya identifikasi manusia ini dilakukan dengan menggunakan wajah maupun kode sandi, akan tetapi dua cara ini memiliki kekurangan karena wajah manusia dapat berubah dari waktu ke waktu, selain itu penggunaan kode sandi juga kurang efektif karena manusia rentan lupa akan kode sandinya, sehingga dalam beberapa tahun terakhir ini, identifikasi seseorang telah dikembangkan dengan menggunakan tubuh manusia sebagai media untuk menggali informasi hal ini disebut dengan biometrik (Purba, 2020).

Biometrik merupakan sistem pengenalan berdasarkan karakteristik yang dimiliki oleh manusia. Hal ini memungkinkan komputer mengenali seseorang melalui bagian tubuh manusia 
yang dianggap unik, stabil, dan tidak berubah dari waktu ke waktu, karena tidak semua bagian tubuh manusia dapat digunakan dalam sistem pengenalan (Devella, 2019). Iris merupakan bagian tubuh yang dapat digunakan dalam proses identifikasi manusia, iris mata merupakan bagian dari ciri-ciri sistem biometrik yang terbagi menjadi dua bagian yaitu ciri fisiologis dan ciri perilaku. Ciri fisiologis berkaitan dengan bentuk tubuh manusia, seperti iris mata, DNA, wajah, sidik jari, retina, bentuk tangan dll. Sedangkan gaya berjalan, suara, dan pola perilaku seseorang termasuk kedalam karakteristik perilaku (Devella, 2018).

Iris mata berfungsi untuk mengendalikan intensitas cahaya yang masuk dengan cara melebarkan atau mengecilkan pupil. Iris yang dimiliki setiap orang berbeda dan memiliki stabilitas sepanjang hidup, kecuali terjadi kerusakan yang tidak disengaja pada iris seperti terjadi kecelakaan. Meskipun sidik jari memiliki fungsi yang sama dengan iris, namun dalam proses pengenalannya iris memiliki keunggulan tersendiri. Karena terlindung oleh kelopak mata, dan pola tekstur yang unik (Al Rivan \& Devella, 2020).

Penelitian tentang pengenalan iris mata telah dilakukan sebelumnya, salah satunya penelitian yang dilakukan oleh (Devella, 2018) mengenai sistem pengenalan iris mata dengan menggunakan Histogram of Oriented Gradient (HOG) sebagai ekstraksi ciri dengan metode algoritma klasifikasi KNearest Neighbours (K-NN) dan Naive Bayes. Penelitian lainnya (Purba, 2020) mengenai perancangan sistem identifikasi biometrik iris mata menggunakan metode transformasi hough sebagai ekstraksi ciri.

Penelitian selanjutnya dilakukan oleh (Bhagat et al., 2017) penelitian ini menggunakan GLCM, LBP dan Gabor Wavelet sebagai metode ekstraksi ciri, dan menggunakan SVM sebagai metode identifikasinya.

Penelitian (Telaumbanua et al., 2019) dalam penelitian ini Sistem pengenalan iris mata menggunakan metode dekomposisi paket wavelet dan jarak Euclidean. Jarak Euclidean digunakan untuk mengklasifikasikan hasil ekstraksi ciri untuk mengidentifikasi citra dengan membandingkan nilai citra uji dengan nilai citra pada database. Menggunakan 150 kumpulan data citra, dengan data training sebanyak 120 citra dan data testing sebanyak 30 citra. Nilai hasil pengujian pada citra yang dikenali sebesar $6,66 \%$, karena bulu mata yang terlalu panjang dan posisi iris tidak berada di tengah, citra tidak dapat dikenali sehingga lingkaran pada iris mata tidak dapat dideteksi selama proses transformasi circle hough.
Penelitian (R. Malutan, S. Emerich, 2016) pengenalan iris dengan mengusulkan dua metode ekstraksi fitur yaitu Histogram of Oriented Gradients (HOG) dan Local Intensity Order Pattern (LIOP) dan Support Vector Machine sebagai algoritma klasifikasi. HOG adalah fitur deskriptor yang digunakan dalam pengolahan citra dan computer vision.

Penelitian (Meidi Mahendra R et al., 2019) KNN digunakan untuk klasifikasi dan DWT sebagai ekstraksi ciri, penelitian ini menggunakan beberapa parameter (termasuk parameter level DWT dan parameter jarak pada NPC) dan menguji noise untuk mendapatkan nilai akurasi 54\%.

Penelitian (Devella, 2019) sistem pengenalan iris mata menggunakan K-Nearest Neighbours sebagai pengklasifikasi dan transformasi cosinus diskrit sebagai algoritma ekstraksi ciri. Hasil penelitian menunjukkan bahwa akurasi pengenalan $\mathrm{K}$ secara keseluruhan $=3$ dan $\mathrm{K}=5$ menghasilkan akurasi yang sama yaitu $70 \%$. Meskipun akurasi dari setiap iris mata yang diuji memberikan akurasi yang cukup baik, namun untuk iris 20 pada saat $\mathrm{K}=9$, akurasi pengenalan kategori iris mata minimum FAR dan FRR adalah $71,67 \%$. Penelitian selanjutnya (Al Rivan \& Devella, 2020) dilakukan dengan menerapkan LBP sebagai ekstraksi fitur dan RBF sebagai pemodelan dengan nilai akurasi tertinggi.

Berdasarkan hal tersebut penelitian ini mengusulkan metode dengan menggunakan berbagai ekstraksi fitur diantaranya haralick, hu-moments, dan HOG, dengan algoritma klasifikasi Logistic Regression (LR), Linear Discriminant Analysis (LDA), $K$ Nearest Neighbor (KNN), Random Forest Classifier (RF), Decision Tree Classifier (CART), Gaussian NB, dan SVM. Hal ini dilakukan untuk menentukan ekstraksi fitur dan algoritma klasifikasi yang mana yang menghasilkan nilai akurasi terbaik dalam pengenalan iris.

\section{METODE PENELITIAN}

Pada penelitian ini dibuat model untuk mengklasifikasikan citra iris dengan menggunakan berbagai metode klasifikasi diantaranya LR, LDA, KNN, RF, CART, NB, dan SVM. Hal ini dilakukan untuk melihat perbandingan hasil klasifikasi dari berbagai algoritma tersebut sehingga dapat ditentukan algoritma yang mana yang mengahasilkan nilai performa yang paling baik. Peneletian ini menggunakan model ekstraksi fitur Hu- Moments, Haralick dan HOG.

Klasifikasi adalah metode pengelompokan objek berdasarkan karakteristiknya. Dalam proses ini, 
klasifikasi dapat dilakukan dengan cara bantuan teknologi maupun secara manual. Klasifikasi manual adalah klasifikasi yang dilakukan oleh manusia tanpa bantuan algoritma kecerdasan komputer, sedangkan dengan bantuan teknologi proses pengklasifikasian menggunakan algoritma (Wibawa et al., 2018). Ekstraksi fitur adalah proses mendapatkan fitur dari citra digital dengan menggunakan metode tertentu untuk menghitung jumlah piksel pada citra (Amirullah, 2018).

Metode penelitian dalam penelitian ini dapat dilihat pada pada Gambar 1. Tahapan metode penelitian ini dimulai dengan akuisisi citra, prapemrosesan, penerapan ekstraksi fitur, klasifikasi dan evaluasi. Total citra yang digunakan dalam penelitian ini berjumlah 100 citra dengan pembagian untuk data training sebesar $90 \%$ dan data testing sebesar $10 \%$. Berikut merupakan tahapan pada penelitian ini:

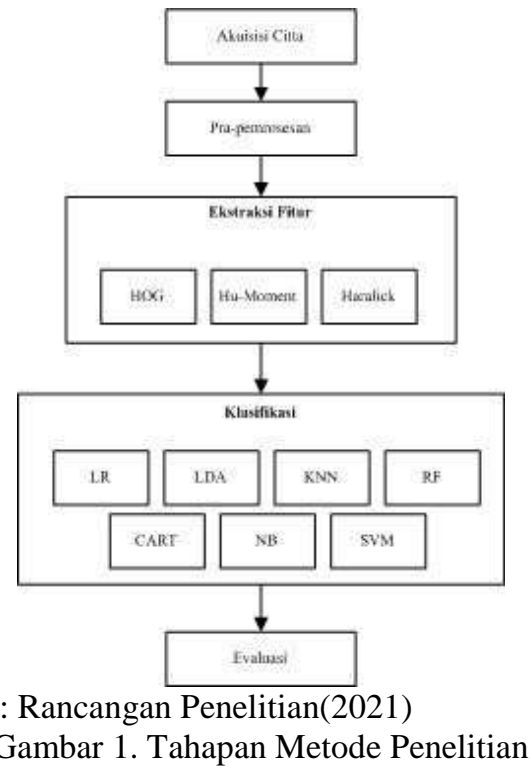

\section{Akuisisi Citra}

Citra yang akan digunakan pada penelitian ini menggunakan MMU iris dataset yang berasal dari Database Universitas Multimedia (MMU1) pada repository kaggle, terdiri dari 46 orang yang masingmasing memiliki 5 citra untuk bagian kanan dan kiri, sehingga total citra dalam dataset ini berjumlah 460 citra dengan dimensi 320x240 pixel. Namun dalam tahap pengujian citra yang digunakan hanya 10 orang artinya hanya 100 citra. Berikut merupakan beberapa citra yang ada pada setia individu:

Tabel 1. MMU iris dataset

\begin{tabular}{|c|c|}
\hline No & Citra Iris \\
\hline
\end{tabular}

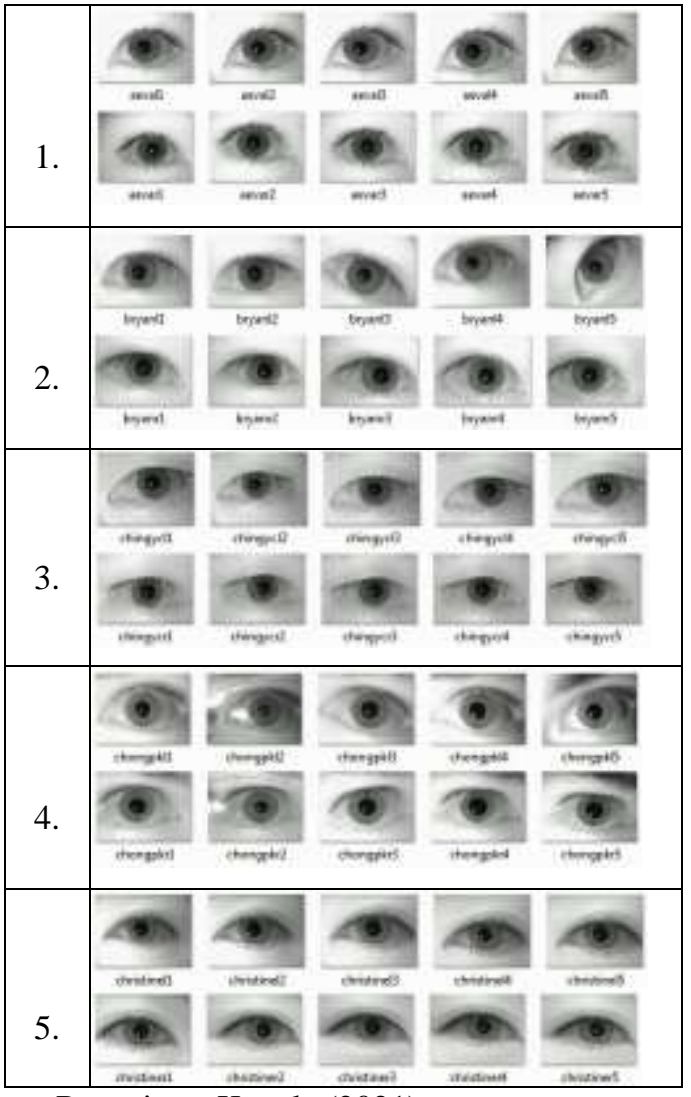

Sumber: Repository Kaggle (2021)

\section{Pra-pemrosesan Citra}

Pada tahap pra-pemrosesan citra dilakukan beberapa proses yang diterapkan pada tiap citra yang terdiri dari penetuan kelas, penetuan ukuran citra dan pembagian data latih dan data uji

\section{Fitur Ekstraksi}

Ekstraksi fitur yang digunakan dalam penelitian ini adalah sebagai berikut:

a. Histogram Of Oriented Gradients (HOG), merupakan metode untuk mendeteksi suatu objek dengan representasi bentuk. HOG bekerja dengan menangkap histogram dari orientasi gradien pada setiap cell yang terbagi dari sebuah citra (Yohannes et al., 2020).

b. Hu-Moments atau Moment Invariant, merupakan metode untuk mengenali sebuah obyek atau ciri dengan menghasilkan 7 fitur yang digunakan. Ciri yang dihasilkan dapat berupa area, posisi, orientasi dan ciri lainnya (Susetya et al., 2017).

c. Haralick, Ekstraksi fitur Haralick merupakan perhitungan statistik yang terdiri dari 14 fitur untuk melakukan analisis objek pada suatu citra digital (Suryanto \& Dodi, 2015).

\section{Algoritma Klasifikasi}

Algoritma klasifikasi yang digunakan dalam penelitian ini adalah sebagai berikut: 
a. Logistic Regression (LR), merupakan metode statistik yang biasa digunakan untuk menganalisis data dengan mendeskripsikan antara variabel respon dengan satu atau lebih variabel prediksi. Variabel respon dari Logistic Regression bersifat dikotomi yang hanya bernilai 1 (ya) dan 0 (tidak), sehingga variabel respon yang dihasilkan akan mengikuti distribusi Bernoulli (Bimantara \& Dina, 2019).

b. Linear Discriminant Analysis (LDA), adalah sebuah teknik klasifikasi sederhana tetapi robust yang bekerja dengan mecari kombinasi linear dari fitur-fitur yang ada untuk memisahkan sampel ke dalam kelas yang sesuai. Akan tetapi, LDA memiliki kelemahan yaitu sebaiknya tidak digunakan untuk data dengan sampel yang lebih kecil dari jumlah fiturnya (Astuti \& Adiwijaya, 2019).

c. K-Nearest Neighbor (KNN), merupakan metode klasifikasi data yang diklasifikasikan dengan menghitung jarak terdekat antara kasus baru dan kasus lama berdasarkan pencocokan bobot yang ada (Qoiriyah et al., 2019).

d. Random Forest Classifier (RF), adalah salah satu metode pohon gabungan berdasarkan klasifikasi dan regresi. Cara kerja Random Forest adalah membangun banyak pohon keputusan selama data pelatihan dan keluaran kelas.Ini adalah model kelas (klasifikasi) atau prediksi (regresi) dari satu pohon (Muslikh et al., 2019)

e. Decision Tree Classifier (CART), adalah metode atau algoritma dalam teknologi eksplorasi data (yaitu, teknologi pohon keputusan). KERANJANG itu sederhana, tapi kuat. CART bertujuan untuk mendapatkan kumpulan data yang akurat sebagai fitur klasifikasi. Selain CART, juga digunakan untuk mendeskripsikan hubungan antara variabel respon (variabel dependen atau variabel dependen) dengan satu atau lebih variabel prediktor (variabel independen atau variabel independen). (Ritno et al., 2018).

f. Gaussian NB (NB), biasanya digunakan untuk merepresentasikan probabilitas bersyarat dari fitur continue pada sebuah kelas $\mathrm{P}(\mathrm{Xi} \mid \mathrm{Y})$ dan dikarakteristikkan dengan dua parameter yaitu mean dan varian (Kurniawan et al., 2017)

g. SVM, SVM bekerja dengan membagi setengah menjadi dua bagian Cluster data menggunakan fungsi linier pada feature space berdimensi tinggi. Proses tersebut memiliki proses untuk menemukan hyperplane terbaik sehingga dapat menggunakan aturan kernel untuk menemukan ukuran margin terbesar antara ruang input dan ruang fitur (Alita et al., 2020).

\section{HASIL PEMBAHASAN}

Penelitian ini menggunakan berbagai ekstraksi fitur yaitu HOG, haralick, dan hu moments serta berbagai algoritma klasifikasi yang terdiri dari LR, LDA, KNN, RF, CART, NB, dan SVM. Hal ini bertujuan untuk mencari ekstraksi fitur dan algoritma klasifikasi yang mana yang menghasilkan nilai akurasi terbaik dalam melakukan klasifikasi citra iris.

Pengujian ini dilakukan dengan sampel sebanyak 10 orang yang masing-masing memiliki 10 citra sehingga total citra yang digunakan adalah 100 citra, dengan dimensi 320x240 pixel dan pembagian data yang digunakan adalah perbandingan 9:1, artinya $90 \%$ untuk data latih dan $10 \%$ untuk data uji. Berikut merupakan hasil pengujian yang telah dilakukan dalam penelitian ini:

1. Hasil Pengujian dengan Ekstraksi Fitur HuMoments

Pengujian pertama dilakukan dengan penerapan ekstraksi fitur satu persatu untuk melihat arsitektur mana yang paling cocok untuk dalam melakukan pengklasifian ataupun identifikasi citra iris. Pada pengujian ini dilakukan penerapan ekstraksi fitur hu- moments terhadap beberapa algoritma klasfikasi yang menghasilkan nilai sebagai berikut:

Tabel 2. Hasil Pengujian Hu-Moments

\begin{tabular}{ll}
\hline Algoritma & Akurasi \\
\hline RF & 0.436111 \\
LDA & 0.336111 \\
KNN & 0.336111 \\
NB & 0.275000 \\
CART & 0.223611 \\
LR & 0.150000 \\
SVM & 0.037500 \\
\hline
\end{tabular}

Hasil Penelitian(2021)

Dari Tabel 2. Hasil Pengujian Hu-Moments di atas dapat dijelaskan bahwa penerapan ekstraksi fitur Hu- Moments terhadap algoritma Random Forest memiliki nilai akurasi terbaik sebesar $43.61 \%$.

\section{Hasil Pengujian dengan Ekstraksi Fitur Haralick}

Selanjutnya pengujian dilakukan dengan menerapkan ekstraksi fitur haralick dengan hasil sebagai berikut:

Tabel 3. Hasil Pengujian Haralick

\begin{tabular}{ll}
\hline Algoritma & Akurasi \\
\hline LDA & 0.605556 \\
CART & 0.484722 \\
\hline
\end{tabular}

Penerapan Metode Pembelajaran Menggunakan Ekstraksi Fitur dan Algoritma Klasifikasi untuk Identifikasi Pengenalan Iris 
Hasil Penelitian(2021)

\begin{tabular}{ll}
\hline RF & 0.458333 \\
NB & 0.455556 \\
KNN & 0.443056 \\
LR & 0.411111 \\
SVM & 0.098611 \\
\hline
\end{tabular}

Dari Tabel 3. Hasil Pengujian Haralick di atas dapat dijelaskan bahwa nilai akurasi yang dihasilkan mengalami peningkatan yang lebih baik meskipun nilai akurasi terbaik diperoleh oleh algoritma yang berbeda dari pengujian sebelumnya, yaitu algoritma Linear Discriminant Analysis dengan nilai sebesar $60.55 \%$.

\section{Hasil Pengujian dengan Ekstraksi Fitur HOG}

Pengujian selanjutnya dilakukan dengan menerapkan ekstraksi fitur HOG dengan hasil yang diperoleh sebagai berikut:

Tabel 4. Hasil Pengujian HOG

\begin{tabular}{ll}
\hline \multicolumn{1}{c}{ Algoritma } & Akurasi \\
\hline RF & 0.802778 \\
LR & 0.741667 \\
KNN & 0.679167 \\
NB & 0.566667 \\
CART & 0.516667 \\
LDA & 0.323611 \\
SVM & 0.025000 \\
\hline
\end{tabular}

Sumber: Hasil Penelitian (2021)

Dari Tabel 4. Hasil Pengujian HOG di atas dapat dijelaskan bahwa penerapan ekstraksi fitur HOG meningkatkan nilai akurasi hampir pada setiap algoritma dibandingkan pengujian sebelumnya, terutama pada algoritma Random Forest yang menghasilkan nilai akurasi terbaik sebesar $80.27 \%$.

4. Hasil Pengujian dengan Gabungan Ekstraksi Fitur Haralick dan Hu Moment

Setelah dilakukan pengujian dengan menerapkan ekstraksi fitur satu persatu, selanjutnya dilakukan penerapan ekstraksi fitur gabungan yaitu ekstraksi fitur haralick dan hu-moments dengan nilai akurasi yang dihasilkan sebagai berikut:

Tabel 5. Hasil Pengujian Haralick+Hu Moment

\begin{tabular}{lc}
\multicolumn{1}{c}{ Algoritma } & Akurasi \\
\hline LDA & 0.730556 \\
RF & 0.606944 \\
NB & 0.577778 \\
KNN & 0.519444 \\
\hline
\end{tabular}

\begin{tabular}{ll}
\hline LR & 0.486111 \\
CART & 0.484722 \\
SVM & 0.061111
\end{tabular}

Sumber: Hasil Penelitian(2021)

Dari Tabel 5. Hasil Pengujian Haralick+Hu Moment di atas dapat dijelaskan bahwa penggabungan ekstraksi fitur belum tentu menghasilkan nilai akurasi yang baik. Hal ini dapat dilihat dari nilai akurasi terbaik yang dihasilkan sebesar $73.05 \%$ diperoleh dari algoritma Linear Discriminant Analysis.

5. Hasil Pengujian dengan Gabungan Ekstraksi Fitur HOG dan Hu Moment

Penggabungan ekstraksi fitur selanjutnya dilakukan dengan menerapan ekstraksi fitur HOG dan humoments yang mengahasilkan nilai akurasi sebagai berikut:

Tabel 6. Hasil Pengujian HOG+Hu Moment

\begin{tabular}{lc}
\hline \multicolumn{1}{c}{ Algoritma } & Akurasi \\
\hline RF & 0.777778 \\
LR & 0.754167 \\
KNN & 0.666667 \\
LDA & 0.655556 \\
NB & 0.579167 \\
CART & 0.529167 \\
SVM & 0.025000 \\
\hline Hasil Penelitian $(2021)$
\end{tabular}

Dari Tabel 6. Hasil Pengujian HOG+Hu Moments di atas dapat dijelaskan bahwa penggabungan esktraksi fitur yang berbeda menghasilkan nilai akurasi yang lebih baik yang diperoleh dari algoritma Random Forest nilai akurasi sebesar $77.77 \%$.

6. Hasil Pengujian dengan Gabungan Ekstraksi Fitur HOG dan Haralick

Penggabungan ekstraksi fitur selanjutnya dilakukan dengan menerapkan esktraksi fitur HOG dan haralick dengan nilai akurasi yang didapat sebagai berikut:

Tabel 7. Hasil Pengujian HOG+Haralick

\begin{tabular}{ll}
\hline \multicolumn{1}{c}{ Algoritma } & Akurasi \\
\hline RF & 0.813889 \\
LR & 0.752778 \\
KNN & 0.641667 \\
LDA & 0.640278 \\
CART & 0.529167 \\
NB & 0.431944 \\
\hline
\end{tabular}




$\begin{array}{cc}\text { SVM } & 0.025000 \\ \text { Sumber: Hasil Penelitian (2021) }\end{array}$

Dari Tabel 7. Hasil Pengujian HOG+Haralick di atas dapat dijelaskan bahwa penggabungan esktraksi fitur HOG dan haralick merupakan perpaduan yang cukup baik karena nilai akurasi yang dihasilkan algoritma Random Forest sebesar 81.38\%. nilai akurasi ini merupakan akurasi terbaik dibandingkan nilai akurasi yang diperoleh dari pengujianpengujian sebelumya.

7. Hasil Pengujian dengan Gabungan Ekstraksi Fitur HOG, Haralick dan Hu Moment

Pengujian selanjutnya dilakukan dengan menggabungkan semua ekstraksi fitur yang digunakan dalam penelitian ini yaitu HOG, haralick dan hu-moments. Pengujian ini menghasilkan nilai akurasi sebagai berikut:

Tabel 8. Hasil Pengujian HOG+Haralick+Hu

\begin{tabular}{lc}
\multicolumn{2}{c}{ Moment } \\
\hline Algoritma & Akurasi \\
\hline RF & 0.802778 \\
LR & 0.766667 \\
LDA & 0.751389 \\
KNN & 0.715278 \\
NB & 0.591667 \\
CART & 0.588889 \\
SVM & 0.025000 \\
\hline
\end{tabular}

Sumber: Hasil Penelitian (2021)

Dari Tabel 8. Hasil Pengujian $\mathrm{HOG}+$ Haralick $+\mathrm{Hu}$ Moment di atas dapat dijelaskan bahwa penggabungan semua ekstraksi fitur menghasilkan peningkatan nilai akurasi hamper pada semua algoritma kecuali algoritma SVM yang menghasilkan nilai akurasi yang tetap sama dengan peneltian sebelumnya, dan algoritma Random Forest yang mengalami sedikit penuruan akurasi, meskipun dalam pengujian ini Random Forest menghasilkan nilai akurasi terbaik yaitu sebesar $80,27 \%$.

Dari beberapa pengujian yang dilakukan dalam penelitian ini, nilai akurasi terbaik sebesar $81.38 \%$ yang diperoleh dari hasil penggabungan ekstraksi fitur HOG dan haralick pada algoritma Random Forest. Selain itu, pengujian ini juga menghasilkan tabel confusion matrix yang merupakan pengukuran performa untuk klasifikasi machine learning dimana keluaran dapat berupa dua kelas atau lebih dan merupakan kombinasi perbedaan nilai prediksi dengan nilai aktual. Berikut merupakan confusion matrix yang dihasilkan dari pengujian ini:

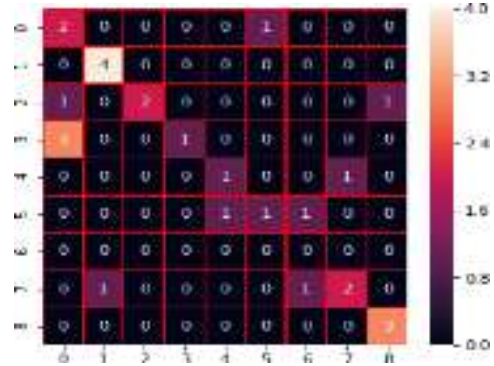

Sumber: Hasil Penelitian (2021)

Gambar 2. Confusion Matrix

Berdasarkan Gambar 2. Confusion Matrix dapat dijelaskan bahwa dari 10 orang yang menjadi sampel dalam pengujian ini, hanya 1 orang yang tidak dapat diprediksi sama sekali yaitu kelas ke 6, sedangkan untuk kelas lainnya terdapat beberapa citra yang menunjukan hasil prediksi dari suatu kelas sesuai dengan hasil sebenarnya.

\section{KESIMPULAN}

Berdasarkan hasil pengujian yang telah dilakukan dalam mengklasifikasikan iris dapat disimpulkan bahwa penggunaan ekstraksi fitur sangat berpengaruh pada nilai akurasi yang dihasilkan. Dalam hal ini pengujian dilakukan sebanyak tujuh kali eksperimen dengan percobaan yang berbedabeda, mulai dari penggunaan satu ekstraksi fitur diantaranya HOG, Haralick, dan Hu-Moments, gabungan dua ekstraksi fitur seperti HOG dan Haralick, Haralick dan Hu-Moments, kemudian HOG dan Hu-Moments, dan yang terakhir gabungan tiga ekstraksi fitur yakni dengan menggunakan ke tiga ekstraksi fitur sekaligus. Dari berbagai eksperimen yang telah dilakukan menghasilkan nilai akurasi terbaik yang diperoleh dari penggabungan ekstraksi fitur HOG dan Haralick pada algoritma Random Forest dengan nilai akurasi sebesar $81.38 \%$.

\section{REFERENSI}

Al Rivan, M. E., \& Devella, S. (2020). Pengenalan Iris Menggunakan Fitur Local Binary Pattern Dan Rbf Classifier. Simetris: Jurnal Teknik Mesin, Elektro Dan Ilmu Komputer, 11(1), 97-106. Https://Doi.Org/10.24176/Simet.V11i1.3717

Alita, D., Fernando, Y., \& Sulistiani, H. (2020). Implementasi Algoritma Multiclass Svm Pada Opini Publik Berbahasa Indonesia Di Twitter. Jurnal Teknokompak, 14(2), 86. Https://Ejurnal.Teknokrat.Ac.Id/Index.Php/Te knokompak/Article/View/792

Amirullah, D. (2018). Sistem Pencarian Semantik 
Impresi Dengan Mekanisme Pembobotan Kombinasi Fitur Warna Dan Fitur Bentuk. Inovtek Polbeng - Seri Informatika, 3(1), 41. Https://Doi.Org/10.35314/Isi.V3i1.332

Astuti, W., \& Adiwijaya, A. (2019). Principal Component Analysis Sebagai Ekstraksi Fitur Data Microarray Untuk Deteksi Kanker Berbasis Linear Discriminant Analysis. Jurnal Media Informatika Budidarma, 3(2), 72. Https://Doi.Org/10.30865/Mib.V3i2.1161

Bhagat, K. S., Deshmukh, R. R., Patil, P. B., Kirange, D. K., \& Waghmare, S. (2017). Iris Recognition Using Radon Transform And Glcm. 2017 International Conference On Advances In Computing, Communications And Informatics, Icacci 2017, 2017-Janua, 22572263.

Https://Doi.Org/10.1109/Icacci.2017.8126182

Bimantara, A., \& Dina, T. A. (2019). Klasifikasi Web Berbahaya Menggunakan Metode Logistic Regression. Annual Research Seminar (Ars), 4(1), 173-177.

Devella, S. (2018). Pengenalan Iris Menggunakan Ekstraksi Fitur Histogram Of Oriented Gradient. Jurnal Teknik Informatika Dan Sistem Informasi, 4(1), 124-134. Https://Doi.Org/10.28932/Jutisi.V4i1.756

Devella, S. (2019). Pengenalan Iris Menggunakan K - Nearest Neighbors Dengan Ekstraksi Fitur Dicrete Cosine Transform. Jtksi, 02(01), 2733.

Kurniawan, B., Fauzi, M. A., \& Widodo, A. W. (2017). Klasifikasi Berita Twitter Menggunakan Metode Improved Naïve Bayes. Jurnal Pengembangan Teknologi Informasi Dan Ilmu Komputer (J-Ptiik) Universitas Brawijaya, 1(10), 1193-1200.

Meidi Mahendra R, Wijayanto, I., \& Aulia, S. (2019). Biometrik Iris Recognition Menggunakan Lbp Dengan Klasifikasi Knn. E-Proceeding Of Engineering, 6(1).

Muslikh, A. R., Santoso, H. A., \& Marjuni, A. (2019). Klasifikasi Data Time Series Arus Lalu Lintas Jangka Pendek Menggunakan Algoritma Adaboost Dengan Random Forest.
Jurnal Riset Dan Konseptual, 4(1), 78-96.

Purba, M. S. (2020). Perancangan Sistem Identifikasi Biometrik Iris Mata Menggunakan Metode Transformasi Hough. 7(2), 117-122.

Qoiriyah, L., Purwanto, H. L., \& Setiyaningsih, W. (2019). Rancang Bangun Sistem Pendukung Keputusan Penentuan Jenis Beasiswa Menggunakan Knn. Jurnal Terapan Sains \& Teknologi Fakultas, 1(2), 64-72.

R. Malutan, S. Emerich, And O. P. (2016). Half Iris Biometrie System Based On Hog And Liop A . Histogram Oforiented Gradients (Hog) Loeal Lntensity Order Pattern (Llop). Conf. Front. Signal Process, 99-103.

Ritno, E. Y. S., Hasibuan, N. A., \& Fadlina. (2018). Implementasialgoritma Clasification Andregression Trees (Cart) Dalam Klasifikasi Ekonomi Keluarga Pada Desadagang Kelambir Tg . Morawa. Majalah Ilmiah Inti, 6(1), 66-72.

Suryanto, \& Dodi, E. (2015). Ekstraksi Fitur Haralick Menggunakan Citra Mikroskop Digital Trinocular Untuk Proses Identifikasi Cacing Penyakit Kaki Gajah. July.

Susetya, H. Y., Rachmat, A., \& Nugraha, K. A. (2017). Implementasi Moment Invariant Untuk Pengenalan Label Buku Perpustakaan Berbasis Android. Jurnal Terapan Teknologi Informasi, 1(1), 21-30. Https://Doi.Org/10.21460/Jutei.2017.11.13

Telaumbanua, K., Sirait, P., Rohana, A., \& Gea, B. (2019). Sistem Pengenalan Iris Mata Menggunakan Metode Wavelet Packets Decomposition Dan Euclidean Distance. 20(2), 105-116.

Wibawa, A. P., Guntur, M., Purnama, A., Akbar, M. F., \& Dwiyanto, F. A. (2018). Metode-Metode Klasifikasi. Prosiding Seminar Ilmu Komputer Dan Teknologi Informasi, 3(1), 134-138.

Yohannes, Y., Pribadi, M. R., \& Chandra, L. (2020). Klasifikasi Jenis Buah Dan Sayuran Menggunakan Svm Dengan Fitur SaliencyHog Dan Color Moments. Elkha, 12(2), 125. Https://Doi.Org/10.26418/Elkha.V12i2.42160 